\title{
PENDIDIKAN ISLAM DALAM PANDANGAN SYEKH NAWAWI AL- BANTANI DAN IMPLIKASINYA DI ERA MODERN
}

\author{
Much. Machfud Arif \\ Institut Agama Islam Nahdlatul Ulama Tuban \\ email : machfud.tuban@gmail.com
}

\begin{abstract}
Abstrak
Imam Muhammad Nawawi al-Jawi (al-Bantani) adalah salah satu tokoh intelektual muslim yang menjadi kebanggan umat Islam Indonesia. Kebanggan kepadanya agaknya tidaklah berlebihan karena keberadaannya telah memberikan kontribusi yang besar terhadap dunia intelektual dan citra Islam di mata dunia Islam. Nawawi al bantani sejatinya merupakan tokoh yang piawai dalam gerakan dan pembaharuan pemikiran pendidikan. Melalui karya-karyanya yang tersebar dipesantren-pesantren tradisional yang sampai sekarang masih banyak dikaji, nama Kiai asal Banten ini sekan masih hidup dan terus menyertai umat memberikan wawasan ajaran Islam yang menyejukkan. disetiap majlis ta'lim karyanya selalu dijadikan rujukan utama dalam berbagai ilmu, dari Ilmu tauhid, fikih, tasawuf sampai ilmu tafsir.

Pemikiran syekh Nawawi telah di kenal bukan hanya di dunia pesantren di Indonesia, tetapi juga di negara-negara Asia Tenggara, bahkan Timur Tengah. Oleh karena itu, kajian-kajian terhadap pemikiran syekh Nawawi, khususnya dalam pendidikan Islam menjadi suatu yang sangat menarik.

Syekh Nawawi al-Bantani telah banyak berjasa meletakkan landasan teologis dan tradisi keilmuan di lembaga pendidikan Islam.pemikiran pendidikanya masih relevan di implementasikan di zaman modern sekarang yang menyangkut nilai-nilai dasar pendidikan dan aktifitas pendidikan islam di indonesia maupun di dunia internasional.
\end{abstract}

Kata Kunci : Nawawi al-Bantani, Pemikiran Pendidikan, implikasi pemikiran pendidikan, implementasi di zaman Modern

\section{PENDAHULUAN}

Dalam sejarah pembaharuan Islam, syekh Nawawi al-Bantani sering disebut-sebut sebagai pemimpin keagamaan yang dianggap penting di dunia Islam, khususnya di Indonesia. Karena di samping sebagai ulama dan guru besar di masjid al-Haram, ia juga sebagai pengarang yang produktif dan pemimpin masnyarakat Islam Indonesia di Makkah. Sehingga pemikiran-pemikiranya dapat memberi pengaruh terhadap perkembangan Islam di Timur Tengah dan Asia Tenggara, terutama Indonesia (Asnawi, DEPAG : 1)

Syekh Muhammad Nawawi adalah seorang ulama yang memiliki reputasi intelektual yang baik. Karena reputasinya di bidang keilmuan Islam itu ia memperoleh gelar Sayyid ulama al-Hijaz, fuqaha dan hukama, imam ulama haramain dan guru berra pada nassyirul ma'arif di Mekkah ( Maragustam, $2006: 1)$

Pemikiran syekh Nawawi telah di kenal bukan hanya di dunia pesantern di Indonesia, tetapi juga di negara-negara Asia Tenggara, bahkan Timur Tengah. Oleh karena itu, kajian-kajian 
terhadap pemikiran syekh Nawawi, khususnya dalam pendidikan Islam menjadi suatu yang sangat menarik.

Syekh Nawawi melalui karyanya, sangat di kenal dikalangan masnyarakat muslim, terutama di dunia pesantren di Jawa. Dalam bidang keilmuan, dia dikenal ahli di bidang teologi Islam, figh, akhlak/tasawuf, bahasa dan kesustraan arab, dan tarikh. sedangkan di bidang kependidikan Islam, nyaris tak terdengar atau luput dari pengamatan, padahal percikan-percikan pemikiran pendidikanya dalam banyak di berbagai disiplin ilmu seperti tafsir, hadis, dan akhlak, tasawuf, syekh Nawawi memilikinya. Tetapi dalam makalah ini penulis condong untuk membahas pemikiran pendidikan yang digagas oleh syekh Nawawi dan implikasinya di era globalisasi.

\section{METODOLOGI}

Metode Penelitian yang digunakan yaitu studi literatur dengan tipe penelitian kualitatif dengan pendekatan kajian analitis literatur. Metode ini menggunakan telaah pustaka. Berbagai sumber pustaka ditelaah untuk saling memperkuat deskripsi yang dipaparkan. Penelitian sebelumnya sebagai sumber info terhadap perkembangan dari kajian penelitian Pendidikan Agama Islam. Kemudian dari penelitian-penelitian tersebut digunakan sebagai dasar kajian penelitian ini.

Analisis data menggunakan cara perbandingan berbagai literatur dilakukan secara obyektif, sehingga hasil penelitian ini dapat menjadi referensi bagi penelitian selanjutnya dan memperkaya dibidang penelitian Pendidikan Agama Islam.

\section{HASIL DAN PEMBAHASAN \\ Sketsa Biografi Syekh Nawawi Al- Bantani}

Muhammad Nawawi Abu Abd AL-Mu'tibin 'Umar bin 'Arabi bin 'Ali al-Jawi al- Bantani, lebih dikenal di kalangan muslim nusantara sebagai syekh Nawawi Banten. Lahir pada tahun 1230 H/1813 M di Tanara, kecamatan Tirtayasa, kabupaten Serang, Banten. Nawawi meninggal dunia di Makkah pada tahun 1314/1879. Makamnya terletak di area pemakaman ma'la, di seberang makam Khadijah, istri Nabi Muhammad, dekat dengan kuburan Asma', putri khalifah Abu Bakar, dan Abdullah bin Zubair, sahabat Nabi.

Nawawi hidup dalam lingkungan ulama ayahnya adalah kyai haji Umar, merupakan seorang ulama yang memimpin masjid dan pendidikan Islam di Tanara. Dilihat dari silsilahnya Nawawi merupakan keturunan keduabelas dari Maulana Syarif Hidayatullah (Sunan Gunung Jati Cirebon) yaitu keturunan dari putra Maulana Hasanuddin sultan Banten ke-1 yang bernama Sunyararas. ( Depaq RI, 1993: 841). Ayahnya seorang guru agama di Tanara dan seoarang penghulu, pemimpin agama yang diangkat secara resmi oleh bupati di bawah pemerintah kolonial Belanda. Ibunya 
adalah Jubaidah, asal Tanara. Ia anak tertua dari empat saudara laki-laki, Ahmad, Said, Tamim, Abdullah dan dua saudara perempuan. Syakila, dan Syahria (Asep , 2004 :50)

Nama syekh Nawawi di belakangnya di tambah al-Tanari al-Bantani serta al-Jawi maksudnya untuk memperjelas tentang identitas daerah asalnya. Nawawi tumbuh dalam lingkup keluarga desa, tetapi selaku putra tertua dari tujuh bersaudara Nawawi tidak hanya berpangku tangan dan bersikap fatalis di dalam hubuangan sindrom keterbelakanganya. Ayahnya yang seorang penghulu kecamatan di Tanara sedikit telah menyokong perkembangan jiwa keagamanya. Di samping juga tekad dan kesadaran dirinya untuk tidak ikut terbawa arus kebodohan yang diciptakan kaum penjajah.

Pada masa kanak-kanak beliau belajar ilmu pengetahuan agama Islam bersama saudarasaudaranya langsung dari ayahnya sendiri. Ilmu-ilmu yang dipelajari meliputi pengetahuan bahasa Arab (nahwu dan sharaf), fikih, tauhid dan tafsir. Pengetahuan dasar tersebut mendorongnya untuk meneruskan pelajaran di beberapa pesantren di Jawa.

Nawawi mulai belajar kepada beberap kyai yang berpengaruh saat itu seperti kyai Sahal dari Banten dan kyai Yusuf dari Purwakarta. Kesemua itu beliau lakukan ketika berumur 15 tahun. Berkat ketekunan dan otaknya yang cerdas maka Nawawi sanggup menyerap bebagai cabang keilmuan yang sesungguhnya lebih cocok diajarkan pada orang dewasa.

Ketaatan dan kesungguhan beliau dipengaruhi oleh penyataan imam Syafi'i (w. 204 H). Imam Syafi'i mengatakan dalam sebuah ungkapan dalam rangka memotivasi murid-muridnya: “Tidak layak bagi orang-orang yang berakal dan berilmu. Untuk mencari ilmu tinggalkanlah negerimu, dan berkelanalah, engkau pasti akan menemukan pengganti orang-orang yang kamu cintai. bersusah payahlah karena sesungguhnya ketinggian derajat dan kehidupan bisa dicapai dengan kesusahan payahan" .

Pernyataan tersebut memacu dan mendorong syekh Nawawi untuk mencari berbagai jenis ilmu agama. setelah belajar di berbagai wilayah di Jawa, maka Nawawi yang ketika itu berumur 15 tahun bertekad menunaikan ibadah haji. Beliau berangkat haji ke Mekkah bersama saudarasaudaranya di usia muda. Setelah menunaikan ibadah haji, ia tidak kembali ke tanah airnya. Ia memperpanjang masa tinggalnya di Makkah selama tiga tahun untuk menuntut ilmu dipusat dunia Islam itu.

Seperti muslim lain dari kepulauan Melayu-Indonesia yang datang ke Mekkah untuk belajar pada masa itu, Nawawi pertama kali belajar kepada guru sarjana jawi yang sudah menetap di makkah. Pertama kali, ia belajar kepada Abdul Gani dari Bima (Nusa Tenggara Barat), Ahmad Khatib dari Ambas ( Kalimanatan Barat), dan Ahmad bin Zaid, syekh agen haji asal Solo, Jawa Tengah. 
Guru-gurunya yang terkenal adalah Sayyid Ahmad Nahrawi, Sayyid Ahmad Dimyati dan Zaini Dahlan (Makkah) serta Muhamamad Khatib al-Hambali (Madinah). Setelah belajar di Makkah dan Madinah, syekh Nawawi bekelana mencari ilmu pengetahuan kenegara-negara lain seperti Mesir dan Syam (Syiria).

Setelah berkelana dan mencari ilmu pengetahuan diberbagai Negara tersebut syekh Nawa wi kembali ke tanah air untuk kembali belajar pada salah seoarang ulama besar di Karawang. Setelah itu beliau kembali ke Tanara untuk mengamalkan dan mengajarkan ilmunya kepada umat yang sangat mengharapkan dan menantikan kehadiran beliau.

Akan tetapi karena kondisi tanah air ketika itu masih berada di bawah penjajahan Belanda, maka setiap gerak gerik ulama diawasi termasuk syekh Nawawi. Karena itu beliau kembali ke Mekkah untuk mengajarkan ilmunya kepada para mahasiswa yang berdatangan dari berbagai Negara. Di Makkah beliau tinggal di perkampuangan Syi'ib sampai akhir hayatnya.

Sebagai seorang alim yang dalam ilmunya, tinggi akhlaknya dan kepribadianya, ikhlas dalam mengajar dan mendakwahkan Islam, tentu saja hasil didikanya menghasilkan ulama-ulama yang besar. Diantara murid-muridnya yang berasal dari Indonesia adalah :

1. KH. Hasyim Asy'ari, berasal dari Tebu Ireng Jombang Jawa Timur.

2. KH. Khalil dari Bangkalan, Madura.

3. KH. Asy'ri dari Bawean.

4. KH. Asnawi dari Caringan , Labuan, Pandeglang, Banten.

Syekh Nawawi al-Bantani dikenal sebagai penulis produktif, khususnya komentar terhadap karya-karya klasik sebelumnya, dalam banyak bidang. Karya-karyanya mencapai seratusan judul. Bidang-bidang ditulis Syekh Nawawi cukup beragam, mulai di bidang Tafsir Hadist, Akidah, Fiqih, dan Tasawuf.

Dalam Bidang Tafsir, beliau menulis Al-Tafsir al-Munir li al-Muallim al-Tanzil al-Mufassir ,an wujuh mahasin al-Taeewil musamma Murah Labid li Kasyfi Maena Quran Majid (yang dikenal dengan nama Tafsir Munir). Tafsir al-Munir sering disejajarkan dengan Tafsir Jalalain, bahkan banyak kalanganyang menganggap lebih baik. Sepuluh tahun setelah terbit kitab tafsir Murāh, Syekh Nawawimeninggal dunia tepatnya 1314H/1897 M dengan meninggalkan karya-karya yang relatif lengkap dan orisinal.

Dalam Bidang Ilmu Akidah beliau menulis antara lain Tîjan al-Darary, Nur al-Dhalam, Aqidah Fath al-Majîd. Pokok pikiran Syekh Nawawi dalam akidah adalah bahwa manusia dalam keadaan tertentu mempunyai pilihan untuk berbuat baik atau jahat. Namun dalam kesempatan lain, seperti dalam soal kelahiran dan kematian manusia tidak mempunyai pilihan apapun, karena semuanya sudah ditakdirkan. Pemikiran ini merupakan pemikiran Asyeariyah. Dalam Bidang Ilmu 
Hadits, beliau menulis Tanqih al-Qaul yang merupakan syarah atas Lubab Hadist, namun di pesantren di Indonesia justru Tanqi al-Qaul lebih terkenal dari Lubab Hadist. Bidang Ilmu Fiqih beliau menulis Sullam al-Munâjah, Nihayah al-Zain, Kâsyifah al-Saja. Kasyifah al-Saja syarah atau komentar terhadap kitab fiqih Safînah al-Najâ, karya Syaikh Sâlim bin Sumeir al-Hadhramy. Kitab fiqih lainnya yang sangat terkenal di kalangan para santri pesantren di Jawa "Uqûd al-Lujain fi Bayân Huqûq al-Zaujain. Dalam bidang fikih, Syekh Nawawi berhasil memperkenalkan dan menancapkan pengaruh Madzhad Syafiei di Indonesia seperti yang kita saksikan sekarang ini.

Bidang Ilmu Tasawuf beliau menulis Qamiee u al-Thugyan, Nashâih al-Ibâd, dan Minhâj alRaghibi. Kitab Nashâih al-Ibâd merupakan syarah atas kitab syarah atas al-Manbaĥâtu ala alIstidâd li yaum al-Mi'âd. Namun di Indonesia Nashâih al-,Ibâd lebih terkenal dari kitab yang disyarahinya. Dalam bidang tasawuf, Syekh Nawawi selalu menekankan bahwa kesucian rohani bisa dicapai dengan cara menjalankan syarie at Islam secara penuh dan konsekwen. Syekh Nawawi mengibaratkan syarieeat sebagai sebuah kapal, tarekat adalah lautan, dan hakikat adalah intan dalam lautan. Intan dalam lautan dapat diperoleh dengan kapal yang harus berlayar di lautan. Karena itu, kapal, laut, dan intan sangat terkait sebagaimana syariat, tarekat, dan hakikat tidak bisa berjalan sendiri-sendiri.

\section{Pemikiran Pendidikan Syekh Nawawi al-Bantani}

Proses pendidikan merupakan arena transfer dan tranformasi. Tujuan pendidikan dalam Islam merupakan arah yang selalu dituju oleh pendidik dalam proses pendidikan. Tujuan ini sangat penting artinya karena tujuan berfungsi sebagai pengakhir aktifitas, mengarahkanya dan merupakan titik pangkal untuk mencapai tujuan-tujuan yang lebih tinggi, dan memberi nilai pada usaha-usaha tersebut.

Term yang dipakai syekh Nawawi yang menunjuk kepada pendidikan dan pengajaran ialah ta'lim, tarbiyah dan ta'dib. Karenanya menyangkut transfer dan tranformasi. Pendidikan tidak hanya menyangkut pendidikan jasmani (praktek/amal), tetapi juga pendidikan intelektual, mental/spiritual yang berjalan sepanjang hidup (long life education). Pengajaran dan pendidikan merupakan kesatuan intregral yang harus berjalan secara bersama-sama. Kepengajaran (transfer) merupakan strategi untuk mengaktualkan pendidikan.

Tujuan Pendidikan Islam

Tujuan pendidikan dalam Islam menurut syekh nawawi merupakan refleksi dari fungsi manusia sebagai ubudiyah dan khalifah. Sebagaimana tercemin dari pendapatnya bahwa tujuan pendidikan dalam Islam (memperoleh ilmu) ada empat yakni : (Maragustam, 2006 : 334)

1. Agar memperoleh rida (rela) dari Allah (mardatillah) dan memperoleh kehidupan akhirat. 
2. Untuk menyingkirkan kebodohan dari dirinya (peserta didik) dan setelah mendapatkan ilmu ia juga ikut mengajari orang lain agar kebodohan itu lenyap.

3. Menghidupkan agama dan mengabdikan Islam dengan sinaran ilmu.

4. Untuk mensyukuri nikmat Allah berupa pemberrian akal dan badan sehat.

Dari empat tujuan pendidikan dalam Islam yang digagas oleh syekh Nawawi al-Bantani, yakni memperoleh ilmu untuk mencari rida (rela) Tuhan dan mencari persiapan kehidupan akhirat adalah merupakan realisasi dari fungsi manusia untuk ubudiyah, sedangkan tujuan lainya berkaitan dengan fungsi manusia sebagai khalifah atau co creator. Maksud manusia ubudiyah ialah semua aktifitas manusia harus dibingkai dengan nilai mardatilah dan kebahagian akhirat. Sedangkan fungsi manusia sebagai co creator (khalifah), adalah bagaimana mengatur kehidupan dan mengolah alam semesta ini kemakmuran bagi manusia sekarang dan generasi mendatang, sekaligus ubudiyah.

Dari tujuan pendidikan yang dipaparkan tersebut mencakup lima aspek yakni, aspek pendidikan akhlak, akal, sosial kemasnyarakatan, jasmani dan aspek profesioanal. Implikasi dari tujuan ini menempatkan syehk Nawawi pada posisi memandang ilmu sebagai sesuatu yang dicari untuk tujuan keilmuan itu sendiri, tetapi juga tujuan untuk diluarnya yakni reformasi sosial (ilmu untuk kemajuan dan peradaban). Mu'allim dalam pelajaranya memegang prinsip metodik yakni memperlakukan tolib sesuai dengan keadanya, seperti seorang dokter memberikan terapi kepada pasienya, sesuai dengan penyakitnya.

Prinsip-prinsip metode pendidikan Islam

Prinsip-prinsip metodik dalam pendidikan Islam adalah menyajikan mata pelajaran harus jelas, dimulai dari yang mudah, yang konkret lalu bertahap pada yang lebih sulit, komplek dan abstrak, dalam penyampaian materi mu'allim haru melihat keadaan tolibnya, menggunakan metode sesuai dengan tingkat kemampuan tolibnya, menghargai dan memperhatikan pendapat dan pertanyan dari tolibnya, tidak menambah pelajaran atau memberikan penjelasan sebelum pelajaran yang terdahulu dipahami, mu'allim tidak mendominasi percakapan sewaktu dalam proses pembelajaran dan adanya prinsip al-tikrar (pengulangan) terhadap pelajaran yang belum dimengerti oleh tolibnya.

Sifat-sifat pendidikan yang dikemukakan oleh para ahli pendidikan Islam termasuk Syekh Nawawi Al-Bantani sangat ketat. Hal ini karena peranan guru dalam Islam tidak sekedar alih ilmu, nilai dan metode, tetapi juga transformasi (membentuk kepribadian peserta didik). Di samping itu diyakini bahwa para pendidik menempati ulama sebagai pewaris para nabi sehingga pendidik harus dapat menjadi teladan bagi peserta didiknya. Menurut Syekh Nawawi tujuan memperoleh ilmu (tujuan pendidikan) ialah mardatillah dan memperoleh kehidupan ukhrawiyah, memberantas kebodohan, memajukan Islam, melestarikan Islam dengan kaidah-kaidah ilmu serta sebagai 
perwujudan dari rasa syukur karena diberi akal dan tubuh yang sehat. Kewajiban bersyukur mencakup aspek keilmuan (ranah kognitif), aspek rasa senang (ranah afektif), dan menggunakan nikmat Tuhan sesuai dengan permintaan pemberi nikmat yakni Allah (ranah psikomotor dan spiritual). (Maragustam, 2007: 2598-259).

Hakikat pendidikan dan pengajaran dalam Islam menurut Nawawi mencakup term ta'lim, tarbiyah dan ta'dib. Pendidikan mencakup transfer of knowledge, transfer of value, transfer of methodology, dan transformasi. Pendidikan mencakup jasmani (praktik/amal), intelektual, mental/spiritual dan berjalan sepanjang hidup dan integral.

Syekh Nawawi menafsirkan bahwa membacakan dalam ayat ini bukan hanya sebatas membacakan saja, akan tetapi membacakan dengan mengarahkan manusia kepada iman, sedangkan makna mengajarkan (ta'lim)Al-kitab, Nawawi memberikan makna yang lebih luas, yaitu mengajarkan dan memahamkan nilai- nilai dari ajaran tersebut serta bagaimana mengimplementasikan ajaran tersebut dalam kehidupan sehari-hari.

Ayat tentang tarbiyah,

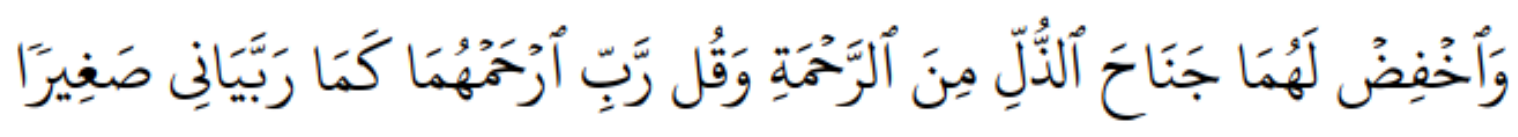

Artinya: Dan rendahkanlah dirimu terhadap mereka berdua dengan penuh kesayangan dan ucapkanlah: "Wahai Tuhanku, kasihilah mereka keduanya, sebagaimana mereka berdua telah mendidik aku waktu kecil". (Al-Isra':17: 24)

Dalam ayat ini tarbiyah lebih ditekankan kepada pendidikan anak diwaktukecil, Syekh Nawawi menafsirkan ayat pertama sebagai perintah bahwa kita wajib berbuat baik kepada kedua orang tua kita dan juga mendoakannya walaupun hanya lima kali dalam sehari, karena kedua orang tua kitalah yang telah mendidik kita dari kecil hingga dewasa.

Ayat tentang ta Ta'dib,

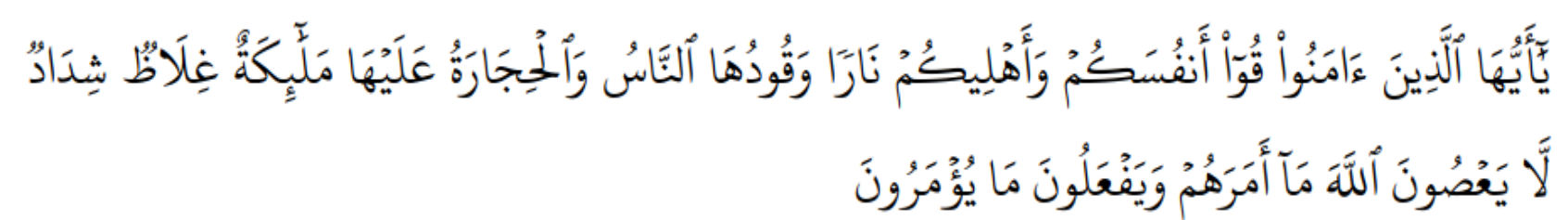

"Hai orang-orang yang beriman, peliharalah dirimu dan keluargamu dari api neraka yang bahan bakarnya adalah manusia dan batu; penjaganya malaikat-malaikat yang kasar, keras, dan tidak mendurhakai Allah terhadap apa yang diperintahkan-Nya kepadamereka dan selalu mengerjakan apa yang diperintahkan". (At-Tahrim : $66: 6$ ) 
Syekh Nawawi mengartikan ta'dib disamakan dengan ta'lim, akan tetapi ta'dib lebih ditekankan kepada pembentukan Akhlaq. Dengan demikian, Nawawi tidak terlalu membedakan antara makna ta'lim dan ta'dib, karena semuanya mengacu kepada trasformasi dalam pendidikan.

Pemikiran syekh Nawawi dalam mengkrontruksi tujuan pendidikan berada pada tujuantujuan idealis dengan nilai-nilai mardatillah dan membangaun kebahagian akhirat, sedangkan tujuan realistis ialah menghilangkan kebodohan, mengabdikan Islam dengan sinaran ilmu, serta mengoptimalkan potensi-potensi akal dan tubuh.

Menurut Syekh Nawawi, dilihat dari kepentingannya ilmu itu dibagi menjadi dua;

a. ilmu Fardhu ain yaitu ilmu yang wajib diketahui oleh semua orang muslim, meliputi ilmu agama; ilmu yang bersumber dari kitab suci Allah dan Sunnah Rasullah SAW

b. Ilmu Fardhu Kifayah yaitu ilmu yang bisa dipelajari oleh setiap orang muslim. Ilmu ini meliputi ilmu yang dimanfaatkan untuk memudahkan urusan hidup duniawi; misalnya ilmu Maatematika, ilmu kedokteran, ilmu teknik, ilmu p ertanian dan ilmu industri. Maka dari itu, setelah sesorang selesai mempelajari ilmu-ilmu fardu ,ain, sebaiknya ia gunakan sisa waktu yang ada untuk belajar ilmu-ilmu fardu kifayah.

Untuk mencapai tujuan pendidikan tersebut memerlukan pemikiran tentang muatan pendidikan Islam. Dari berbagai pernyataan Syekh Nawawi, hal utama yang diberikan dalam proses pendidikan adalah masalah ilmu-ilmu keagamaan yang wajib personal. Sedangkan yang paling utama dari kewajiban personal itu ialah iman tauhid.

Realisasi fungsi manusia ubudiyah dan khalifah tidak hanya tercermin dalam tujuan pendidikan sebagai akhir suatu proses pendidikan, tetapi juga tercermin dalam proses pendidikan seperti adanya etika seorang terhadap ilmu.

Etika Pendidik dan Peserta Didik

Menurut Nawawi pendidik derajatnya disamakan dengan ulama' yang sangat dihargai kedudukannya oleh Allah SWT. Ia juga mengatakan Ulama' adalah orang yang mempunyai ilmu dan mengamalkannya (guru), mereka menjadi penerang bagi kehidupan manusia disetiap zamannya dan sesungguhnya amal sedikit yang disertai dengan ilmu itu akan lebih bermanfaat dari pada amal banyak dengan tanpa ilmu.

Pendidik di lembaga pendidikan sekolah disebut dengan guru, baaik guru taman kanakkanak, sekolah menengah, kyai di pondok pesantren, dan lain sebagainya. Tugas guru tidak hanya menerima amanat orang tua untuk mendidik, melainkan juga mau menerima dari setiap orang yang memerlukan bantuan untuk mendidiknya. 
Syekh Nawawi sependapat dengan imam Nawawi tentang etika memperoleh ilmu dengan memberi dalil (argument). Dia berpendapat bahwa etika memperoleh ilmu itu ada delapan yaitu : ( Maragustam, 2006 :337-338)

1. Untuk diamalkan. Syek Nawawi memberi argumen dengan mengutip pendapat salaf al-salih yakni Anas r.a yang berkata: bahwa ulama itu cita-citanya (himmah) adalah penjagaan, pengawasan dan perlindungan (ri'ayah), sedangkan orang bodoh (sufaha') keinginannya adalah mengabarkan (riwayah).

2. Menyebarkan ilmu yang telah ia peroleh. Argumen syehk Nawawi merujuk firman Allah (QS. Al-Taubah: 9:122).

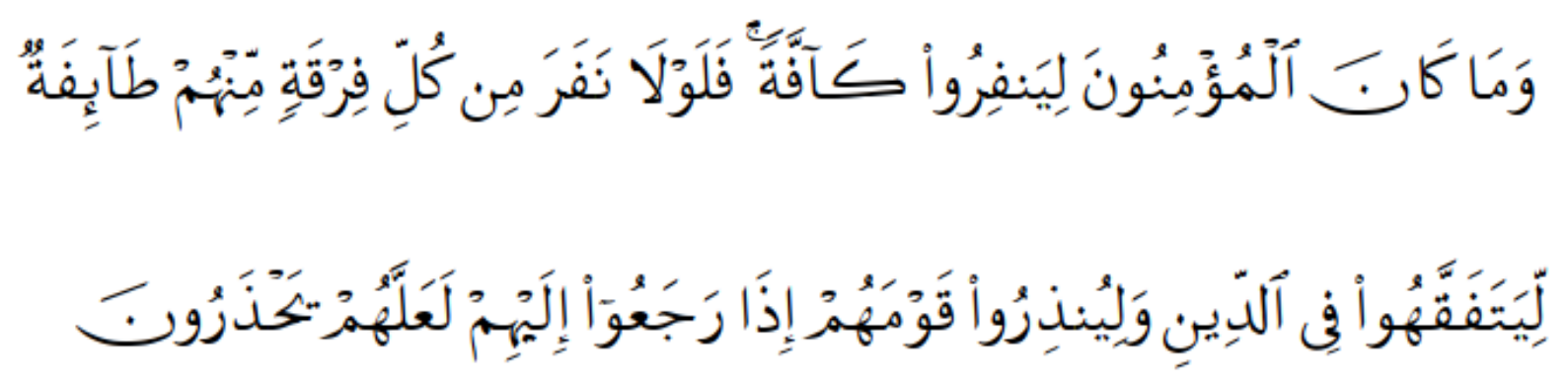

Yang artinya : "Tidak sepatutnya bagi mukminin itu pergi semuanya (ke medan perang). Mengapa tidak pergi dari tiap-tiap golongan di antara mereka beberapa orang untuk memperdalam pengetahuan mereka tentang agama dan untuk memberi peringatan kepada kaumnya apabila mereka Telah kembali kepadanya, supaya mereka itu dapat menjaga dirinya."(QS. Al-Taubah: (9) :122)

3. Tidak boleh sombong dan melakukan pertengkaran.

4. Murah memberikan ilmu jika diberi upah. Namun penuh perhitungan dan kikir jika tidak diberi upah. Dalam al-Quran disebutkan:

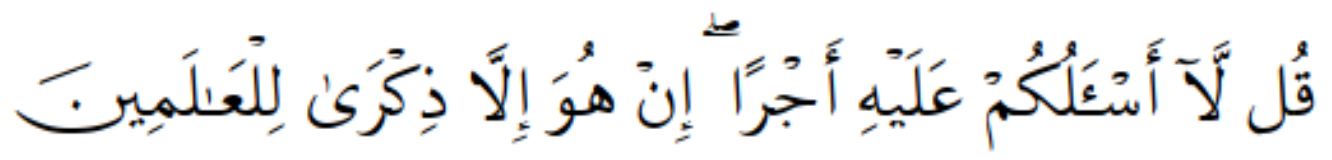

Artinya : Katakanlah: "Aku tidak meminta upah kepadamu dalam menyampaikan (Al-Quran)."

Al-Quran itu tidak lain hanyalah peringatan untuk seluruh ummat. (QS. Al-An'am: 6: 90).

5. Berani mengatakan, 'tidak tahu', kepada sesuatau yang ia tidak tahu.

6. Tawadu (rendah hati). (QS. Al-Furqan :25: 63).

7. Sanggup memikul segala yang menyakitkan dan menyusahkan dalam memberi nasehat dan mengikuti salaf al-salih tentangnya.(QS.Luqman: 31 :17)

8. Berniat mengajarkan ilmunya itu terhadap orang yang membutuhkanya.

Walaupun syekh Nawawi sependapat dengan imam Nawawi tentang nilai-nilai yang dijunjung tinggi dalam memperoleh ilmu. Namuan dia mengemas dan memperkuat pendapatnya 
dengan memberi hujjah (argument) baik melalui pengutipan ayat-ayat al-Quran, hadis-hadis sahih atau lemah, melakukan analogi, atau mengutip pendapat para salaf al-salih. Dengan demikian syekh Nawawi mengadakan proses nalar bayani (menggunakan dalil) untuk sampai pada penguatan pendapatnya. Inilah salah satu khas pemikiran dari syekh Nawawi.

Mu'allim dan pendidik merupakan pribadi-pribadi yang mendapat kehormatan dalam Islam. Karena pendidik adalah profil manusia yang setiap hari didengar perkataanya, dilihat dan mungkin ditiru prilakunya oleh murid-muridnya di sekolah (Hasan dan Beni, 2010 : 93) Menurut syekh Nawawi etika pendidik mempunyai kriteria yang sangat ketat karena seorang pendidik merupakan contoh bagi para peserta didiknya. Oleh karena itu, syekh Nawawi mengklasifikasikan sifat atau ahklak pendidik ada 17 kriteria yaitu :

1. Menerima pertanyaan-pertanyaan murid dengan penuh kesabaran.

2. Selalu bermurah hati dalam berbagai hal.

3. Merendahkan diri di depan teman duduknya.

4. Tidak sombong, kecuali kepada orang yang terang-terangan zalim untuk memperingatkan kezalimannya, karena sombong kepada orang yang sombong itu adalah shadaqah sebagaimana tawadhu (merendah diri) kepada orang yang tawadhu.

5. Bersikap tawadhu ketika berada di tengah-tengah acara pertemuan.

6. Mencegah dari bercanda dan senda gurau.

7. Ramah kepada murid ketika mengajar dan tidak menyuruh tergesa-gesa kepada murid yang tidak pandai bertanya.

8. Memperbaiki anak yang tidak cerdas dengan pengajaran yang baik.

9. Tidak marah dan tidak menyindir murid yang bodoh.

10. Tidak merasa segan untuk berkata "tidak tahu" atau "Allah Yang Maha Tahu”, jika suatu masalah belum dikuasainya.

11. Mendorong semangat kepada yang bertanya agar pertanyaannya dapat dipahami dan persoalannya dapat dijawab dengan baik.

12. Dapat menerima alasan orang lain dan mendengarkan, walaupun alasan itu berasal dari musuh/tidak sepaham.

13. Mengikuti haq (kebenaran), dan kembali kepada haq ketika melakukan kesalahan dalam berbicara atau keyakinan, walaupun haq itu berasal dari orang yang lebih rendah.

14. Mencegah murid dari setiap ilmu yang membahayakan agama seperti ilmu sihir dan astrologi.

15. Mencegah murid dari keinginan untuk menggunakan ilmu yang bermanfaat bukan karena Allah.

16. Mencegah murid dari kesibukan dengan fardhu kifayah sebelum menyelesaikan fardhu ain. 
17. Menginstrosfeksi diri sendiri lebih dahulu, sebelum memerintahkan orang lain mengerjakan kebaikan, dan sebelum melarang orang lain agar menjauhi keburukan dengan melaksanakan perintah syara' dan menjauhi larangannya, agar murid mengambil teladan darinya.

Sedangkan etika peserta didik menurut syek Nawawi diklasifikasikan menjadi tiga belas yaitu :(Maragustam,2006 :363-364)

1. Lebih dulu memulai penghormatan, salam dan meminta izin ketika memasuki majelis.

2. Mempersedikit bicara dan mempersedikit sesuatu yang diperbolehkan ketika dihadapan gurunya.

3. Tidak mengatakan/berbicara hal yang tidak ditanyakan.

4. Tidak bertanya tentang sesuatu sebelum meminta ijin terlebih dahulu atau tidak bertanya sebelum ada persoalan.

5. Tidak mengkontradiksikan pendapat gurunya dengan pendapat lain.

6. Tidak menunjukkan pendapat yang berbeda dengan pendapat gurunya, karena anggapan peserta didik bahwa dirinya lebih mengetahui kebenaran dalam masalah itu. Sikap yang demikian akan mengurangi sopan santun dan mengurangi berkah ilmunya.

7. Jangan bertanya kepada teman gurumu ditempat gurumu, dan tidak teseyum ketika terjadi pembicaraan.

8. Tidak menoleh ke kiri dan ke kanan ketika berada di depan gurunya, tapi duduk dengan menundukkan mata, diam, sopan, dan tidak menggerak-gerakan badan, seolah-olah ia sedang shalat.

9. Tidak bertanya ketika pendidik tampak bosan dan bingung.

10. Berdiri ketika pendidik berdiri, untuk menghormatinya.

11. Tidak menguntit pendidik ketika keluar majelis, untuk mengajak bicara dan bertanya.

12. Tidak bertanya kepada pendidik di jalan, tetapi harus menunggu pendidik sampai dirumahnya atau tempat peristirahatanya.

13. Tidak berburuk sangka terhadap perbuatan pendidik yang secara lahiriah, menurut pandanganmu tidak diridai Allah, karena pendidik itu lebih mengetahui rahasis-rahasia perbuatanya sendiri.

Peserta didik sebagai makhluk educandum dan educandus menurut Syekh Nawawi sangat memperhatikan lingkungan kebudayaan termasuk pendidikan dan sosialnya. Kehidupan peserta didik berada dalam suatu kontrak sosial. Eksistensi peserta didik berada dalam interdependensibaik secara sosial maupun lingkungan kebudayaan. Pengaruh lingkungan luar terhadap peserta didik sangat signifikan. Untuk itu Syekh Nawawi membuat etika peserta didik, agar lebih selektif dalam memilih lingkungan sosial dan teman dalam pergaulan, Berhubungan dengan hal itu maka para ahli 
pendidikan Muslim dituntut membentuk peserta didik mempunyai peer group yang kondusif di tempat pembelajarannya, mengingat dari sini ia akan banyak menyerap pelajaran dan mendapatkan rangsangan kognitif, afektif, dan psikomotorik yang positif.

\section{Implikasi Pemikiran Pendidikan Syekh Nawawi AL-Bantani di Era Modern.}

Pemikiran Syekh Nawawi al-Bantani tentang pendidikan mempunyai relevansi dengan pendidikan pada masa sekarang atau pada era modern ini. Banyak aspek atau sudut pandang yang bisa digunakan untuk melihat relevansi pemikiran Syekh Nawawi al-Bantani tentang pendidikan.

Persoalan pendidikan merupakan masalah manusia yang berhubungan dengan kehidupan. Selama manusia ada, maka selama itu pula persoalan pendidikan ditelaah dan direkontruksi dari waktu-kewaktu, baik dalam arti makro seperti kebijakan pendidikan, politik pendidikan, maupun arti mikro, seperti tujuan, metode, pendidik dan pembelajar, baik konsep filosufinya maupun tataran praktiknya. Aksentuasinya pada pendidikan, karena masalah kehidupan manusia, pada umumnya dicari pemecahannya melalui pendidikan (Maragustam,2010:178).

Sebagai implikasi dari pandangan Syekh Nawawi tentu terdapat dampak positif edukatif dan juga terdapat dampak negatif edukatifnya. Dampak edukatif positifnya adalah rasa tanggung jawab yang sangat kuat telah menghujam pada pemikiran pendidikannya, dan mengukuhkan rasa tanggung jawab moral. Penghargaannya terhadap persoalan pendidikan Islam sangat tinggi, bahkan menilainya sebagai wujud tanggung jawab keagamaan yang sangat luhur. Tugas mengajar dan belajar tidak sekadar sebagai tugas-tugas profesi kerja dan tugas-tugas kemanusiaan tetapi lebih jauh dari itu yakni sebagai tuntutan kewajiban agama. Tanggung jawab dan kewajiban agama sebagai titik sentral baik dalam kontruksi tataran konsep maupun tataran aplikasi pendidikan. Atau dengan kata lain jika tuntutan tidak sejalan dengan tuntutan keagamaan, maka yang harus didahulukan ialah tuntutan keagamaan.(Tim Penyusun, 2011:267-268).

Adapun dampak negatif edukatifnya. Syekh Nawawi menjadi term al-'ilm yang dalam nash bersifat mutlak, bersifat muqayyad (terbatas), hanya pada ilmu keagamaan, dan kecenderungan pencapaian spiritual yang lebih menonjol. Mendorong pemikiran pendidikan Islam ke arah pengabaian urusan dunia dengan segala kemanfaatan dan amal usaha yang sebenarnya boleh dinikmati. Oleh karena itu pengabaian urusan dunia, maka ilmu-ilmu yang bersifat keduniaan dikuasai oleh non muslim dan menjadi lemahnya pelaksanakan amar makruf nahi munkar dalam reformasi dan transformasi sosial yang bermoral. Padahal penguasaan dunia sebagai sarana pendakian kebahagiaan di akhirat. 
Sampai saat ini, pendidikan tetap dianggap sebagai penolong utama bagi manusia untuk menjalani kehidupan ini. Darinya, muncul sebuah tesis ektrim bahwa maju mundurnya suatu peradaban bangsa ditentukan oleh keadaan pendidikan yang dijalani bangsa itu (Shofan, 2004 :11)

Pendidikan Islam bukan sekedar proses penanaman nilai- nilai moral untuk membentengi diri dari akses negatif globalisasi. Tetapi yang paling urgen adalah bagaimana nilai-nilai moral yang telah ditanamakan pendidikan Islam tersebut mampu berperan sebagai kekuatan pembebas (liberating force) dari himpitan kemiskinan, kebodohan, dan keterbelakangan sosial budaya ekonomi.

Seiring dengan perkembangan ilmu pengetahuan dan teknologi di bidang informasi dan transportasi, pendidikan Islam baik dari segi konsep maupun realitas pengamalan nilai-nilai spiritual keagamaan menghadapi babak baru dan tantangan yang sangat krusial. Hal itu disamping penguasaan iptek dikendalikan oleh Barat, juga dalam iptek khususnya berbagai media seperti media internet dan televisi pasti membonceng sosial budaya, misi, dan kurikulum tersembunyi (hidden curriculum).Media tersebut dapat dijadikan alat yang sangat ampuh menanamkan atau merusak tatanan nilai-nilai spiritual keagamaan, untuk mempengaruhi atau mengontrol pola fikir seseorang.

Kemajuan Ilmu pengetahuan dan teknologi (Iptek) dibidang transportasi dan informasi menjadikan belahan dunia semakin kecil dan mengglobal. Dengan teknologi modern telah memungkinkan terciptanya komunikasi bebas lintas benua, lintas negara, dan menyelusup di ganggang sempit di perkotaan dan pedesaan, melalui media audio (radio) dan audio visual (televisi, internet, dan lain-lain). Hampir tidak ada relung-relung kehidupan yang belum tersentuh modernitas, termasuk aspek kehidupan keagamaan. Akibat dari berbagai media ini, khususnya televisi, dapat dijadikan alat yang sangat ampuh untuk menanamkan atau, sebaliknya, merusak tatanan nilai-nilai spiritual keagamaan, untuk mempengaruhi atau mengontrol pola pikiran seseorang oleh mereka yang memegang kendali terhadap media tersebut.

Berdasarkan klasifikasi ilmu menurut syekh Nawawi, maka materi pendidikan Islam harus dimulai dari ilmu-ilmu kewajiban personal, kemudian ilmu-ilmu kewajiban komunal dan sunnah komunal. Namun di antara yang kewajiban personal, yang paling penting ialah ma'rifatullah berupa iman tauhid. Bahkan iman tauhid (tauhid uluhiyah, tauhid rububiyah dan tauhid as-asma' wa alsifah) menjadi inti dan pembentuk struktur paling dalam dari semua ilmu-ilmu keagamaan yang diberikan dalam kurikulum pendidikan Islam.

Prinsip-prinsip pendidikan Islam harus menyatukan nilai-nilai spiritual keagamaan dengan nilai-nilai kebendaan keduniaan, bahkan tujuan pendidikan Islampun harus mengarah dan mengakar nilai-nilai tauhid ini. Pendiidikan Islam mengarah pada teosentris yang ma'rifatullah, disamping 
antroposentris yang mengarah kepada kehidupan dunia saja. Antroposentris merupakan bagian yang integral dari teosentis (teoantropesentrisme) (Maragustam,2006:436)

Implikasinya ialah pertama, jika falsafah antroposentris mengatakan bahwa keberhasilan pendidikan dan kegagalan pendidikan ditentukan oleh faktor endogen dan eksogen, sementara falsafah teosentris bahwa keberhasilan dan kegagalan tidak hanya berhenti disitu, tetapi masih ada faktor lain, dengan kata lain, Islam mengakui keberhasilan pendidikan Islam sangat ditentukan oleh hereditas (endogen) dan lingkungan (eksogen), namun harus atas bi ma'unatillah atau biiznillah. kedua, menyeimbangkan antara pendidikan moral-spiritual dan pendidikan akal. Ketiga, mementingkan pendidikan jasmani (tubuh) dan pendidikan rohani. Keempat, menyeimbangkan antara kepentingan individu dan kepentingan masnyarakat. Kelima, tanggung jawab pendidikan Islam berawal dari tanggung jawab keluarga, kemudian beralih kepada lembaga pendidikan lainya.

Mengenai tujuan pendidikan, disamping kecenderunganya menjadikan tujuan-tujuan keagaman sebagai tujuan yang berada di dalamnya tetapi juga berada diluarnya yakni ilmu untuk menghilangkan kebodohan dari umat manusia. Sebagai implikasi dari pandanagan syekh Nawawi tentu terdapat dampak positif edukatif sebagai kelebihan darinya dan juga terdapat dampak negatif edukatif sebagai kekuranganya. Dampak edukatif positifnya ialah rasa tanggung jawab yang sangat kuat telah menghujam pada pemikiran pendidikanya, dan mengukuhkan rasa tanggung jawab moral itu.

Penghargaanya terhadap persoalan pendidikan Islam sangat tinggi, bahkan menilainya sebagai wujud tanggung jawab keagaaman yang sangat luhur. Tugas mengajar dan belajar tidak sekedar sebagai tugas-tugas profesi kerja semata dan tugas-tugas kemanusiaan, tetapi lebih jauh dari itu yakni sebagai tuntutan kewajiabn agama.

Era modern/globalisasi saat ini pemikiran beliau tentang pendidikan akhlak yang dikemas dalam pendidikan Islam sangat relevan dimana arus informasi yang begitu cepat sangat berpengaruh terhadap karakter dan gaya hidup masyarakat. Pengaruh-pengaruh budaya asing yang bertentangan nilai-nilai Islam dan norma-norma sosial sangat mudah diserap dan diadopsi oleh generasi milenial saat ini. Sangat berbahaya jika tidak dibentengi dengan penanaman nilai-nilai Islam yang bisa memperkokoh keyakinan sehingga dapat menghaluskan akhlak peserta didik. Di sinilah pentingnya pemikiran beliau diimplementasikan dalam kegiatan belajar mengajar maupun kegiatan lain yang biasa dilakukan dalam kehidupan bermasyarakat.

Tanggung jawab keagamaan sebagai titik sentral dalam pendidikan Islam, di samping tanggung jawab kemanusiaan baik dalam kontruksi tataran konsep maupaun tataran aplikasi pendidikan. Tuntutan insaniyah (kemanusiaan) tidak sejalan dengan tuntutan ilahiyah (keagamaan), maka yang harus didahulukan dan dimenangkan ialah tuntutan keagamaan. Karena kokohnya 
tanggung jawab pendidikan keagamaan dalam diri syekh Nawawi, berimplikasi juga dalam tataran dana pendidikan. Menurutnya dana pendidikan Islam tidak hanya dibebankan kepada individu pembelajar, keluarga dan pemerintah, tetapi juga dibebankan kepada orang-orang yang mampu dikalangan umat Islam sebagai kewajiban komunal. Dalam perspektif pendidikan Islam modern, penyelenggaraan pendidikan bermutu akan lebih mudah dapat dicapai apabila disupport dengan dana yang memadai dan tersistematis dengan baik.

\section{PENUTUP}

\section{Kesimpulan}

Pemikiran pendidikan dari syehk Nawawi mempunyai ciri khas tersendiri, beliau merupakan ulama besar yang dikenal di Indonesia maupun dunia internasional, Term yang dipakai syekh nawawi yang menunjuk kepada pendidikan dan pengajaran ialah ta'lim, tarbiyah dan ta'dib. Pendidikan tidak hanya menyangkut pendidikan jasmani (praktek/amal), tetapi juga pendidikan intelektual, mental/spiritual yang berjalan sepanjang hidup atau long life education yaitu dari ayunan (mahdi) sampai meninggal (lahdi).

Tujuan pendidikan dalam Islam menurut syekh Nawawi merupakan refleksi dari fungsi manusia sebagai ubudiyah dan khalifah. Sebagaimana tercemin dari pendapatnya bahwa tujuan pendidikan dalam Islam (memperoleh ilmu) ada empat yaitu:

1. Agar memperoleh rida (rela) dari Allah (mardatillah) dan memperoleh kehidupan akhirat.

2. Untuk menyingkirkan kebodohan dari dirinya (peserta didik) dan setelah mendapatkan ilmu ia juga ikut mengajari orang lain agar kebodohan itu lenyap.

3. Menghidupkan agama dan mengabdikan Islam dengan sinaran ilmu.

4. Untuk mensyukuri nikmat Allah berupa pemberrian akal dan badan sehat.

\section{DAFTAR RUJUKAN}

Asnawi, Pemahaman Syaikh Nawawi Tentang Ayat Qodar dan Ayat Jabar dalam Tafsirnya Marah Labid (Suatu Studi Teologi Islam). Jakarta :Badan Litbang dan Diklat DEPAG RI.

Basri, Hasan dan Beni Ahmad Saebani, Ilmu Pendidikaa Islam (Jilid II), Bandung: Pustaka Setia, 2010.

Depaq RI, Ensiklopedi Islam, (Jakarta: Anada utama), 1993.

Iqbal, Asep Muhammad, Yahudi dan Nasrani dalam al-Quran, (Jakarta: Mizan) 2004.

Siregar, Maragustam, Pemikiran Pendidikan Syekh Nawawi Al-Bantani, Yogyakarta: Datamedia, 2007.

Maragustam, Mencetak Pembelajar Menjadi Insan Paripurna (Falsafah Pendidikan Islam), Yogyakarta: Nuha Litera, 2010. 
Ide-Ide Sentral Syekh Nawawi al-Bantani Tentang Pendidikan Islam,Yogyakarta: Disertasi UIN SUKA, 2006.

Shofan, Moh, Pendidikan Paradigma Profetik (Upaya Konstruktif Membongkar Dikotomi Sistem Pendidikan Islam), Jogjakarta: IRCiSod, 2004.

Tim Penyusun, 2011, Filsafat Pendidikan Islam, Seri 2, Yogyakarta: KOPERTAIS Wilayah III UIN Sunan Kalijaga. 